\title{
Reframing the role of lead users in radical innovations: an open innovation perspective
}

\author{
Wim Vanhaverbeke* \\ Department BEW, Hasselt University, \\ Agoralaan Gebouw D, 3590 Diepenbeek, Belgium \\ and \\ Vlerick Leuven Gent Management School, \\ Vlamingenstraat 83, 3000 Leuven - Belgium \\ and \\ ESADE Business School, \\ Av. Pedralbes, 60-62, 08034 Barcelona, Spain \\ Fax: + 3216623663 \\ E-mail: wim.vanhaverbeke@uhasselt.be \\ ${ }^{*}$ Corresponding author

\section{Jingshu Du} \\ Hasselt University, \\ Agoralaan, Building D, 3590 Diepenbeek, Belgium \\ E-mail: jingshu.du@uhasselt.be
}

\begin{abstract}
Developing a strong relation with lead-users can have a strong effect on the commercial success of radical innovations. We consider lead-user interaction as an important yet underexplored research topic in open innovation. In particular, we seize three themes defining the role of lead users. First, open innovation requires that the role of lead users is not analysed only at the dyad level but also at the value network level. Second, we use the innovation funnel as a tool to analyse the dynamics between lead users and the innovating firm. Finally, we show how outbound innovation activities of the innovating firm have a profound impact on the relationship between the innovating firm and its lead users.
\end{abstract}

Keywords: open innovation; lead-user; value-network; value creation; value capturing; business model.

Reference to this paper should be made as follows: Vanhaverbeke, W. and $\mathrm{Du}, \mathrm{J}$. (2010) 'Reframing the role of lead users in radical innovations: an open innovation perspective', Int. J. Business Environment, Vol. 3, No. 2, pp.202-220.

Biographical notes: Wim Vanhaverbeke is a Professor of Strategy and Organisation at the University of Hasselt (Belgium) and a Visiting Professor at Vlerick Leuven Gent Management School (Belgium) and ESADE (Spain). He teaches strategy, innovation management, corporate venturing new business development and international management. He has published in international journals such as Journal of Management Studies, Organization Science and Organization Studies and serves on the editorial board of the Journal of Engineering and Technology Management, Strategic Organization and the International Journal of Technology Marketing. He is Co-Editor with Henry Chesbrough and Joel West of Open Innovation: Researching a New Paradigm, 


\begin{abstract}
a book about the research challenges related to open innovation. He is extending research about open innovation and open business models By setting up 'Exnovate', a network of excellence for managing and organising open innovation, and by doing joint research with different universities and companies around the globe.

Du Jingshu is a PhD student at Hasselt University, in the Department of Business Economics. She studies open innovation and R\&D globalisation. Her research interests include innovation management, open innovation and technology development. She has published papers at national and international levels.
\end{abstract}

\title{
1 Introduction
}

In this study, we intend to reframe the role of lead users in radical innovations by merging insights from open innovation with the existing literature on lead user cooperation in the context of radical innovations. Furthermore, we focus on technology driven, industrial innovations that are developed to a large extent in a business to business (B2B) context. Radical or breakthrough innovations have been defined in different ways. Leifer et al. (2000, p.5) define them as follows: “... radical innovation concerns the development of new business or product lines - based on new ideas or technologies or substantial cost reductions - that transform the economics of a business and therefore require exploration competencies". Radical innovations are thus a product or process innovation that has the potential for significant improvements in performance or cost.

The role of lead users in the development and commercialisation of radical innovations has been explored by several scholars. Following von Hippel, we assume that lead users differ from ordinary users with respect to two characteristics. First, lead users face needs months or years before the majority of the users encounter them. Second, they can benefit significantly from obtaining a solution to those needs and therefore will be highly motivated to engage in the innovation process (von Hippel, 1986). There has been a burgeoning literature on the role of lead users innovation and the management of the relationships between them and the innovating companies. However, most of the research was directed towards communities of users in software development or products where the creativity of individual users plays a crucial role in the development of the product (Dahlander and Magnusson, 2005; Henkel, 2006; von Hippel, 2005). The role of lead users in technology driven, industrial environments has also been analysed (Leifer et al., 2000; Mc Dermott, 1999; McDermott and O'Connor, 2002; O’Conner et al., 2008). Managing relations between the innovating firms and user communities is quite different from lead user interactions of large industrial companies that have a deep understanding of science based technological know-how and intend to create new business opportunities in collaboration with lead users.

Lead user innovation can also be analysed as the co-creation of a new product or business by different companies and it is in this way a particular form of open innovation. During the last two decades, an increasing number of large firms have abandoned the closed innovation system in favour of a more 'open' innovation model (Arora et al., 
2001; Arora, 2002; Chesbrough, 2003; Chesbrough et al., 2006). Large, industrial firms nowadays use flexible innovation strategies relying heavily on externally sourced technology. As a result, corporate venturing investments, strategic alliances and technology licensing play a crucial role in boosting innovation success. These firms use open innovation to improve the performance of their existing business, but they also tap into external technology sources to create new businesses or to transform the company in line with the corporate strategy. Science based, radical technological innovations are a major source of new business developments and business transformation. Innovating companies are progressively building the required knowledge base in cooperation with external partners (O'Connor, 2006; O'Connor et al., 2008).

Hence, open innovation is an appropriate research framework to analyse the introduction of radical, technology based innovations in collaboration with lead users. However, to our knowledge most open innovation scholars focused on the relationship between large innovating firms and upstream players such as universities, research labs, and specialised suppliers, or with specific service companies and knowledge brokers such as Innocentive, Ninesigma Yourencore and others. Lead users have largely been neglected so far, although different authors have been researching the interaction with user communities in a business-to-consumer (B2C) context. In this study, we propose to reframe the role of lead users in the development and commercialisation of technology based radical innovations using the open innovation perspective. Open innovation offers a specific framework to analyse the cooperation between the innovating firm and its innovation partners and therefore has the potential to give a fresh look at the lead user interaction in radical innovations. However, since open innovation focuses on firms' interactions with technology suppliers and not on user interaction, we also claim that the open innovation framework should be adapted to understand and take advantage of the potential of lead user interaction.

Connecting open innovation to the existing literature about lead user interaction for the development and commercialisation of radical innovations results in three themes reframing the role of lead users.

First, research about lead user interaction has focused on individual relationships between the innovation firm and lead users (Lyn et al., 1996; Lettl et al., 2006; McDermott and O'Connor, 2002). These studies have led to a number of recommendations for managing relations with lead users at the dyad level. However, lead user research should not only focus on the dyad level but also at the value network level in order to link the role of customers to the open innovation strategy of firms. We start with the observation that technology by itself has no commercial value. Technologies only add value to customers or customers' customers when they can be translated into major improvements in performance or lower costs for these 'targeted customers'. However, most publications about lead user interactions implicitly assume that the lead users coincide with the targeted customers. This is however, not the case for many radical innovations as they require the establishment of a new value network with different players along the value chain (Normann and Ramirez, 1993; Normann, 2001; Vanhaverbeke and Cloodt, 2006). Target customers can be end consumers (e.g., individuals consuming fresh GM-tomatoes with improved flavour while the biotech firm introducing the tomatoes is an upstream company) or other players downstream the value chain. This implies that an extensive network of partners along the value chain have to be involved in the development and commercialisation of the radical innovation. As a result, we argue that the focus of lead user research should migrate from the dyad level to the 
value network level. We will illustrate this shift by means of a radical innovation developed by a European chemical specialties producer who invented a special laser additive that can be added to a polymer to enable laser marking.

Second, radical innovations require a long period before they reach the market and therefore a funnel concept is instrumental for their analysis. The funnel is a central concept in the analysis of both open innovation and radical innovations (Cooper, 1990; Cooper and Kleinschmidt, 1994), but the consequences for successful collaboration with external partners has not been explored in depth. Hence, we will focus on the dynamics of the relationship between innovators and their lead users from idea generation till market launch. This dynamic view on the relationship will reveal that 'lead user' is an ambiguous concept covering a whole range of innovation partners with different roles in the innovation process.

Finally, open innovation "...means that valuable ideas can come from inside or outside the company and can go to market from inside or outside the company as well." [Chesbrough (2003), p.43]. In open innovation, companies look inside-out and outside-in across the fuzzy-frond end, the development and the commercialisation stage (Docherty, 2006). This implies that the traditional view in which innovating firms and lead users jointly turn a radical innovation into a new product or process is only one of the many possible outcomes. In the era of open innovation, innovating firms have the possibility to licence out technologies, to exit external ventures in which they are involved, to spin-out internal ventures or to commercialise a technology as a new product or application. Hence, co-developing a new product with lead users is only one of the many options to engage in a user relationship in open innovation. Whether the innovator intends to licence technologies, to spin-out a venture or to develop new products will have a profound impact on the way the innovator collaborates with lead users.

The role of lead-users in the development and commercialisation of radical innovations will be illustrated by several case studies (Eisenhardt, 1989; Gummesson, 2007a, 2007b; Yin, 2003). The cases that are presented in this study illustrate the development process of radical innovations at DSM. This is a Dutch Specialty Chemicals and Materials company that is active worldwide: in 2008, the group had annual sales of EUR 9.3 billion and employed about 23,500 people. These different cases were originally developed to analysed radical innovations in a B2B setting. They were not developed to analyse the role of lead-users as this is only one dimension of the development and commercialisation of radical innovations. As a result, we should consider the case studies as illustrations of the arguments we develop. For data collection, we relied on semi-structured interviews with experts and managers at DSM at different points in time in the period 1997-2007. One case study required several interviews with different people that were involved in the radical innovation project. A typical interview took between two and four hours. Respondents included corporate managers, project managers and technical staff of the innovation teams. This primary interview data was complemented with secondary material in the form of intermediate business plans and corporate presentations. Respondents were regularly contacted by telephone or e-mail for follow-up conversations and clarification questions.

The remainder of this paper is organised as follows. We start in Section 2 with the analysis of how innovating companies and lead users can jointly create value and how the latter is appropriated by both types of actors. As value creation and appropriation are part of a business model approach, we also discuss the role of lead-users in each dimension of the business model. Next, we take a more dynamic approach by looking at the role of 
lead users in different phases of the funnel. Section 4 focuses on open innovation and the challenges for lead user interaction in radical innovations. Finally, in Section 5 we wrap up the conclusions of the study, followed by a discussion about the implications of this study for theory and practice.

\section{Creating and appropriating value with lead users: the role of the value network}

Interaction with lead users is a crucial but complex aspect of the development and commercialisation process of radical innovations. In this section, we explain how lead user interaction can contribute to value creation and appropriation and how it can help to conceive and implement an appropriate business model for the radical innovation. Introducing the 'value network' concept is necessary to understand how value is created and captured by different actors when the innovating firm's lead users and (potential) customers differ from target customers (i.e., those that are targeted to benefit from the innovation).

\subsection{Creating customer value}

We start from the observation that technology by itself has no economic value. The value of a technological invention remains latent until it is commercialised in some way (see also Chesbrough, 2003). In order to understand how an innovation creates value, we have to make a distinction between three types of actors: target customers, customers and lead-users. Customers can be defined as those actors to whom an innovating firm is selling or intends to sell in the future. Target customers (sometimes also called end-users) are those actors for whom an innovation is expected to create value. Lead users display two characteristics:

1 they face needs that will be general in a marketplace - but face them months or years before the bulk of the marketplace encounters them

2 They expect to benefit significantly by obtaining a solution to those needs (von Hippel, 1986).

In this context, it is also interesting to quote Danneels (2004, p.255-256): "I also have observed a misguided critique of the "lead-user methodology", the famed approach to creating new products formulated by von Hippel (1986) and colleagues. Unfortunately, Christensen and Bower (1996, p.211) noted in parentheses that the axiom to "stay close to your customers" is supported by the research of von Hippel (1986). However, the detractors of the lead-user method fail to appreciate that lead users are not necessarily current customers. In fact, most often they are not customers at all. In contrast, the lead-user technique may be a great way to identify promising disruptive technologies (for an illustration, see von Hippel et al., 1999). This misunderstanding may be blamed on a confusion of terminology. Even Christensen and Raynor (2000, p.43) use the term lead customers [see also Christensen and Bower (1996), p.207]. We urge scholars and practitioners to be careful to distinguish 'lead customers' and 'lead users' and to understand the latter concept in terms of the research stream started by von Hippel over two decades ago." In the next paragraphs we show that target customers, customers and 
lead users can be three different groups of actors in a value network. The three groups can coincide but this is highly unlikely in the case of radical innovations.

The value of a radical innovation for (potential) target customers will ultimately determine its economic value. As a result, a market-oriented approach is crucial for the success of a radically new product. This implies a thorough understanding of target customers' needs and wants, the competitive situation and the nature of the market (Cooper and Kleinschmidt, 1994). Nevertheless, this market orientation is missing in the majority of firms' technology driven new product projects (Cooper, 1990). Especially for discovery driven innovations, it is crucial that attention is directed to the integration of the customer perspective.

In some cases, recognising the commercial value of radical innovations is relatively easy. Take for instance the Micabs case. The innovating company, DSM, discovered a chemical that independent of the polymer to which it is added enables high quality laser marking. ${ }^{1}$ Segments ranging from security card producers to synthetic wine cork producers value the innovation and the technology is spreading to numerous application areas the development manager had not even thought of at the beginning. High quality laser marking does not require to invent new applications, it just replaces conventional marking techniques in a broad range of existing applications like animal identification, synthetic corks, plastic caps and closures, security and credit cards, cable wire and tubes, film and laminate, etc. Consequently, this is a radical technology commercialisation process that is going exceptionally fast since the technological discovery in May 2002.

The economic benefits for customers are straightforward in this case as the value of marking applications was already in place long before the new laser marking technique of DSM was invented. This new technique has a number of advantages: it has an outstanding performance (unparalleled laser marker performance, retention of chemical resistance, mechanical and electrical properties and no background discoloration), it lowers production costs, it is highly versatile as it can be used in many polymers and processing techniques and it is safe and easy to handle. However, recognising the value for radical innovations is in most cases much more complex. On one hand, radical innovations are usually challenging for the innovating company because it is not obvious which applications or markets might benefit from it. On the other hand, customers are in most cases not capable of recognising the value of a new technology for their markets. This is not really surprising since they can only partly articulate their needs. Hamel and Prahalad (1994) argue that there are many unexploited opportunities because companies only meet the articulated needs of current customers; the commercialisation potential of radical innovations lies in many cases in latent needs instead of articulated ones (Slater and Nayer, 1998). A strong focus on existing customers might blind the search for latent needs (Christensen, 1997). Some scholars have developed methods for digging deeper into unarticulated customers' needs (Aaker et al., 2000; Leonard and Rayport, 1997). Once these unarticulated needs are identified, potential customers have to be educated about the value of the product and how their value activities can be enhanced using the new product. This is basically a mutual learning process in which the innovating company and lead users discover where and how added value can be created in the value chain of downstream industries.

The Dyneema fibre, another breakthrough product of the same company offers a nice example $^{2}$. The Dyneema is a high performance fibre. Fibres have different technical characteristics such as strength, modulus, elongation, density, energy absorption and resistance to abrasion, moisture, UV-radiation and chemicals. New performance materials 
are usually performing better on some but not on all technical characteristics for a particular application. Identifying the right combination of these characteristics determines how valuable the product will be as a business solution for a particular application.

Strong fibres might for instance be used in personal armour applications such as helmets, bullet proof vests and protective shields in which high impact resistance and low weight are essential. In other applications however, other technical features may be essential. In ropes, strength, low elasticity, abrasion resistance, UV-light and moisture resistance are the 'value creating' technical characteristics. Different combinations of these characteristics lead to a broad range of potential applications. Combinations of technical characteristics may indicate that a new application might be better than competing products in terms of technical performance but it does not inform us about its potential commercial success. As a result, the process of creating value from a radical technological innovation might be complex when the potential applications cannot be identified in advance. We focus on this value creating process in the next section.

\subsection{Translate technical characteristics into customer value}

The technical characteristics and performance of the new product vis-à-vis those of existing products are the basis for the value propositions of these products in the market. The technical characteristics as such are by no means sufficient to convince potential customers to use an innovative product. Potential customers have to translate these technical characteristics into unique value propositions that the customer understands and values. We illustrate this with Dyneema, a high performance fibre developed and commercialised by DSM. Strong fibres can for instance, be used in the rope industry, but rope manufacturers are not necessarily interested in stronger materials. Why would a rope maker need a fibre that is 15 times stronger than steel when fabricating a thicker rope out of traditional materials provides the same technical characteristics in a satisfactory and cost-effective way? Moreover, these new products are in most cases sold at a premium price compared to substitutes (with inferior technical characteristics).

The creation of customer value is based on the idea of how the use of the new product can add value to the customer or the customer's customers. The sources of value creation or the value drivers are the factors that enhance the total value created within the value chain of the customer. The technical features of a new product create value only if a particular feature can improve the functioning of one or more value activities of the customer or target customers more downstream in the value chain. Usually, a combination of several product features determines the value for the customers. The product can be successfully sold in applications where this set of features is superior to competing offerings and where customers are willing to pay a premium for that advantage.

Take fishing nets as another Dyneema application. Fishing nets made of the strong fibre are stronger, lighter and last longer than nylon nets. As the fibre is strong, nets can have very narrow twines compared to the normally used polyamide and polyolefin based nets. This enables commercial fishermen to fish more efficiently: the narrow twines decrease drag in the water, saving time and/or fuel or they can use larger nets increasing productivity. The value of this application is obvious for fishermen and they are willing to pay a premium price for it. In this case, the targeted customers are not the customers of the innovating firm (fishing net manufacturers) but customers of the customers. This 
application furthermore shows that innovating companies sometimes have to manage the whole value system in order to get the innovation introduced in the market.

It is important to notice that different types of customers (in different application markets) each value other combinations of several (but not all) technical features of the fibre. In other words, the set of technical features that create value varies according to the application. The innovating firm can determine the different sets of valuable technical features by interacting with lead users from the different application markets. This is illustrated for the Dyneema fibre in the following table.

Table 1 Value creation by combining different technical characteristics per application: the case of the Dyneema fibre

\begin{tabular}{|c|c|c|c|c|c|c|c|c|c|c|}
\hline & 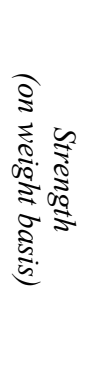 & 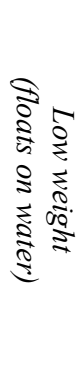 & 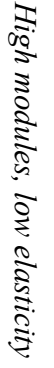 & $\begin{array}{l}\overrightarrow{0} \\
0 \\
\vdots \\
\vdots \\
\vdots \\
\vdots \\
0 \\
0 \\
0 \\
\vdots \\
0 \\
0 \\
\vdots \\
\vdots \\
0 \\
0\end{array}$ & 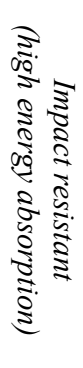 & 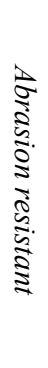 & 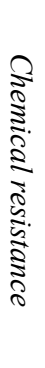 & 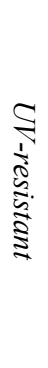 & 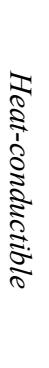 & 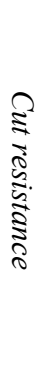 \\
\hline Ropes & $\overline{\sqrt{ }}$ & $\overline{\sqrt{ }}$ & $\overline{\sqrt{ }}$ & $\sqrt{ }$ & & $\sqrt{ }$ & & $\overline{\sqrt{ }}$ & & \\
\hline Nets/fishing lines & $\sqrt{ }$ & & $\sqrt{ }$ & $\sqrt{ }$ & & & & $\sqrt{ }$ & & \\
\hline Personal armour & & $\sqrt{ }$ & & & $\sqrt{ }$ & & & & & \\
\hline Sportswear & & $\sqrt{ }$ & & & & $\sqrt{ }$ & & & $\sqrt{ }$ & $\sqrt{ }$ \\
\hline $\begin{array}{l}\text { Filtration in food and } \\
\text { chemical industries }\end{array}$ & $\sqrt{ }$ & & & & & & $\sqrt{ }$ & & & \\
\hline
\end{tabular}

Source: compiled from various interviews with Dyneema managers

This table indicates that Dyneema can be used in different applications by combining a set of technical characteristics that jointly create value for a (target) customer. The interesting point is that DSM engineers and management were in many cases initially not aware how different characteristics could create value for a particular application. This required detailed knowledge from particular industries and applications that only lead users possessed: the joint learning process between engineers of the innovating firm and lead users leads to a growing understanding of the technical possibilities of the product and how they can be translated into benefits for particular applications.

\subsection{Capturing value from radical innovations}

Breakthrough applications not only have to create value for customers, but they should also be profitable in a sustainable way. Profitability requires that the innovating firm can capture part of the value created by the radical innovation. Capturing value from applications of breakthrough innovations that improve the performance of customers' product or reduce their operating costs is related to the so-called 'value based pricing' strategy. This strategy starts from the value created in a particular application and part of that value is captured by the firm depending on its negotiation position vis-à-vis its 
customers. When radical innovations can be used in different application, they will also usually be priced differently, depending on the relative value they generate for the customer.

Close interactions between the innovating firm and lead users during the development phase of a radical innovation are necessary to understand how the innovation can create value for a particular group of potential customers. These frequent interactions over an extended period of time also reveal the cost structure of different value activities of the lead user's business. As lead user interaction provides the innovating firm interesting information about the lead user's business model, the former is well informed as to how much value can be created by breakthrough innovations and consequently, how much of that value it can appropriate.

\section{Lead user interaction and business model development}

Chesbrough and Rosenbloom (2002) argue that business models play a crucial role in the transition from technological characteristics into the creation of economic value. "The business model provides a coherent framework that takes technological characteristics and potentials as inputs, and converts them through customers and markets into economic inputs. The business model is thus conceived as a focusing device that mediates between technology development and economic value creation." [Chesbrough and Rosenbloom (2002), p.532]. The functions of the business model are:

1 how to articulate the value proposition

2 how to identify potential customer or market segments

3 how to structure the value chain in the company to produce and distribute the offering

4 the estimation of the cost structure and profit potential of the offering

5 how to position the company in the value network

6 how to formulate the competitive strategy (Afuah and Tucci, 2001; Chesbrough and Rosenbloom, 2002; Magretta, 2002).

Without analysing the role of business models in detail, it is a small step to frame the role of lead users in a business model. Business models have been used so far to analyse how innovative companies can establish profitable businesses by creating value for (potential) customers, but, to our knowledge, business model thinking has not been related to the interaction between the innovating company and lead users. The advantage of using the business model concept in the analysis of the role of lead users is two-fold. First, it directs the attention of the interaction between the innovating firm and the lead users on value creation and appropriation, i.e., two crucial strategic aspects in developing a profitable business as we have mentioned before. A business model is a mediating construct between technology and economic value which gives lead users and potential customers a central role in the process of generating value from technical inventions. A new technology can only become a commercial success by analysing how potential customers' value chain activities can be enhanced by using the technology. Second, the business model also indicates that the development and commercialisation of radically 
new products entails much more than identifying the value proposition and the market segment that will be served. An innovating company does not only create customer value but it also has to identify the value chain and eco-system that is required to create the new product and how it will appropriate part of the created value. Appropriating value depends on the power balance between the company, its customers, suppliers, competitors, new entrants, and complementors (Brandenburger and Nalebuff, 1996; Porter, 1980). This in turn requires a careful analysis of process and cost structure, given the value proposition and the value chain chosen, the management of value network and the formulation of the competitive strategy based on the business model (Chesbrough, 2003).

Radical innovations are quite heterogeneous and as a result, some of these functions of the business model will be more difficult to solve in one case, while other functions might be puzzling in another case. Take for instance a radically new process innovation for the production of performance rubber that significantly decreases capital costs and variable production costs. The economic benefits for customers are straightforward in this case. Since this is a major process innovation, there is no need to articulate the value proposition or to identify the market segment. However, the estimation of cost structure and pricing strategy are crucial for the commercial success of the innovation. The oligopolistic structure in the rubber industry offers the option to sell the technology to a competitor or joining forces with one of them. Compare this with the Dyneema case: determining the cost structure and pricing strategy is important, but the identification of interesting applications and the shaping and fine-tuning of the value proposition are serious management challenges in this setting. The Dyneema case illustrates nicely that imagining and validating potentially interesting applications for a technology driven radical innovation might be a very risky and slowly evolving process. Learning about potential applications and customers is crucial but it is also challenging since it requires a relation based on trust in order to find out how particular technical characteristics of technology can deliver value for a specific application.

We have already mentioned that translating technological characteristics of radical innovations into valuable economic output for potential customers is a difficult process. The role of lead users should not be analysed solely within the context of the dyadic relationship between the innovating firm and the lead user. We should rather start from a business model that analyses how a set of firms in the value chain jointly create value by introducing a new product and appropriate part of that value for themselves. In the case of the Dyneema fishing nets this set of firms includes DSM, the fishnet manufacturers and the fishing industry. A biotech firm who intends to strengthen cotton fibres has to find different innovation partners in the value going from seed companies, over farmers and packers, to the textile and garment manufacturers. A food specialty manufacturer who intends to introduce a radically new solution for obesity has to involve all the downstream channel partners to successfully develop and commercialise the product. This broader framework shifting the attention from the dyadic relation between the two firms towards the value network will allow us to better understand the role of the lead user.

In short, a business model is a promising concept to understand whether radical innovations can be turned into profitable businesses or not. However, there is also a need to refine our thinking about business models: They are usually analysed in a static way but they should be considered as the outcome of a dynamic process that turns radically 
new technologies into profitable businesses in which the analysis of lead user interaction plays a critical role. We discuss this in the next section.

\section{Differentiating the role of lead users in different phases of the funnel}

Radical innovations require - almost by definition - an extensive period before they reach the market. Therefore, the funnel is a central concept in the analysis of both open innovation and radical innovations (Cooper, 1990; Cooper and Kleinschmidt, 1994). Innovating firms diligently use a stage-gate process to reduce the initial uncertainties in subsequent steps. The funnel concept is an interesting management tool for innovating firms, but it is not taking the collaboration with external key players such as lead users into the spotlight. Interestingly, the open innovation framework (Chesbrough, 2003) heavily draws on the funnel concept and makes its boundaries permeable so that external players come into the picture. Chesbrough has highlighted the role of technology providers (universities, research labs, IP-brokers, high-tech start-ups, etc.) but remains relatively silent about customer driven innovation and the role of lead users. In this section, we focus on the role of lead users in developing radical innovations adopting a dynamic approach that is inherent to the funnel. We make a distinction between early and late stages in the funnel.

\subsection{Opportunity recognition in early stages}

Radical innovations are high-risk ventures for innovating firms because of the uncertainty the innovating company is confronted with. Uncertainty is especially high in the first stages of the funnel. Leifer et al. (2000) distinguish uncertainty into market, technological, resource and organisational uncertainty. Market uncertainty is particularly relevant in the case of radical innovations (Davidow, 1986; Moriarty and Kosnik, 1989; Mohr, 2001; Shanklin and Ryans, 1987). In a context of radical innovation, market uncertainty typically relates to "the challenge of understanding markets that may not yet exist or that will be fundamentally transformed by the introduction of the radical innovation" [Leifer et al. (2000), p.75]. Besides market uncertainty, firms have also to cope with technological uncertainty when they start a radical innovation project. New technologies are initially unstable in their functional performance and a set of economically feasible applications need to be identified and realised (Leifer et al., 2000). Resource and organisational uncertainty refers to the unpredictable swings in organisational support and resources that are allocated for radical innovation projects (Leifer et al., 2000). In large firms, business units constantly compete for resources. When the company faces a financial crisis resources are likely to be drained away from radical innovation projects in favour of incremental innovations with a clear short-term return. In this situation, managers focus on the realisation of short-term gains, not on growth engines for the company in the long term.

These three types of uncertainty are crucial in understanding radical innovations but within the context of open innovation and lead users' role in developing radical innovations, there should be more emphasis on 'relational uncertainty'. Relational uncertainty between two or more innovation partners is frequently analysed in terms of transaction cost economics (Williamson, 1975, 1985) and is the result of distrust, asymmetric information and potential lock-in situations. However, relational uncertainty 
is not only the result of transaction cost considerations. One can also take a cognitive perspective on uncertainty. Different firms have different cognitive structures which they have been building up in the past (Weick, 1979). When an innovating firm and lead users start to cooperate, there can be quite some confusion as both firms cannot understand each other because of the differences in cognitive structures. The opportunity recognition literature has been analysing this in detail (O'Conner et al., 2001a, 2001b; Rice et al., 2002a, 2002b; Veryzer, 2003).

We illustrate this with the early history of the fishing net applications of Dyneema. In 1986, Dyneema managers were approached by engineers from Hampidjan, a prominent fishing net manufacturer based in Iceland. Hampidjan was founded in 1934 and is nowadays one of the largest suppliers to the worldwide fishing industry, serving customers all over the world. The company tries to differentiate from competitors through innovation. Pioneer research and development in both materials and fishing gear is part of the cultural heritage of the company. The firm also has a history of cooperating with skippers and fishing firms to continuously increase effectiveness of industrial fishing.

In 1986, Hampidjan engineers wanted to explore the potential applications of Dyneema for industrial fishing nets since the existing material for nets [high density polyethylene (HDPE)] was a mature product. Dyneema managers could not understand why Hampidjan's people were enthusiastic about Dyneema as a new material for fishing nets. DSM managers were convinced that Dyneema's most important performance parameter was strength per unit of weight. Dyneema also has a low density, so that Dyneema ropes float on water. A fishing net made of Dyneema would float, making the strength per unit of weight performance feature irrelevant. DSM had no prior experience with the fishing industry and it took a long time before both parties came to the mutual understanding that for this specific application the smaller twine diameter is the valuable performance feature instead of strength per unit of weight. Smaller twines lead to significantly less drag in water than fishing net of similar size and strength made out of HDPE. This, in turn, offers fishermen the advantage of economising on fuel and engine power or to increase their catch by fishing with larger nets on the same boat.

For this application, strength per unit of diameter is the determinant performance parameter instead of strength per unit of weight. The fishing net application was the first application in which diameter is more important than weight. DSM managers had a hard time how the 'diameter logic' could be applied to the Dyneema fibre because of their existing way of thinking that was shaped by earlier applications of the fibre. Later on, they discovered that the fishing net application was not the only application in which diameter is more important than weight.

\subsection{Lead user involvement in the late stages}

Lead users can be valuable partners for innovating firms over the whole length of the funnel but their role changes as the radical innovation project migrates through the funnel. The business model concept which is a central concept in open innovation might help us to understand how the role of lead users shifts when a radical innovation proceeds from the fuzzy front end towards the launch of a first application is. Radical, technology driven innovations usually start with some vague ideas how a technological invention can be turned into a profitable application. The business model is gradually constructed in the earlier phases of the funnel together with lead users. Once the customer segment is 
targeted and the value proposition takes shape, the relationship between the lead user and the innovating firms changes considerably and can lead to conflicts if the process is not managed correctly.

The reason is that, once the different dimensions of the business model crystallises during the development of the radical innovation, both partners know how the value will be created and how much value will be created in the end. At that point, the partners can start to think about their own position and how they expect to make profits from the radical innovation. Value appropriation considerations can become a considerable problem in the relationship between the innovator and the lead user. The power of a lead user depends on different factors. First, its power vis-à-vis the innovating firm decreases when there are other lead users with whom the innovator can collaborate. Second, the lead user has less power when its role in developing the market or in establishing the value network is small. Next, lead users can have considerable negotiation power when they are a major customer for existing products of the innovator. Similarly, they have a better bargaining position when the cost structure is unknown to the innovating firm.

As in other situations, the distribution of the total value created thus depends on bargaining power of the different players (Brandenburger and Nalebuff, 1996). However, we should not forget that in the cooperation with lead users the quality of the cooperation determines the success of the venture and total value created. As a result, capturing value has to be considered jointly with value creating strategies. Therefore, there is always a tension that has to be managed between the necessity to invigorate the collaboration on one hand and to guarantee firm level profitability on the other hand. Good collaborative deals can help a lot in this matter (Bamford et al., 2003).

\section{Open innovation and new challenges for lead user interaction in radical innovations}

In the closed innovation model, innovating firms have in theory two options. Either a radical innovations leads to a successful introduction of a new product, or it fails, in which case the technology is mothballed. If the radical innovation is co-developed successfully with a lead-user, the latter will benefit from the introduction of a new product or process. However, if the radical innovation fails, then the lead user usually ends up with empty hands and in most cases has already stopped the cooperation with the innovating company because the economic benefits of the innovation did not materialise as expected. On average, innovation partners will kill a project too late because they have only the choice between a failure and a successful launch of the new product. As they want to avoid the failure scenario they will continue to invest in the project even when it is already clear that it has almost no chance to succeed.

The open innovation framework changes this situation considerably because in this framework there are different ways to benefit from a particular innovation. Figure 1 illustrates the different possibilities. In open innovation, innovating firms and lead users can turn a radical innovation into a new product or process. But in contrast to closed innovation, open innovation offers innovating firms additional options: they can licence out technologies, spin-out internal ventures or divest new businesses that perform below the preset growth and profitability criteria. Consequently, innovating firms do not have to think in dichotomous terms of success and failure. If a breakthrough innovation cannot be transformed into a new business for the company, the latter can still make a profit by 
licensing out the technology or spin-out the venture. These options are not 'failures' but alternative ways to exploit a technology that cannot be transformed into a new product or business for the innovating firm. Managers will, in this situation, discontinue a project early on considering the different options to generate cash from the technology. These alternative options also create opportunities and challenges for lead-users.

Figure 1 Outside-in and inside-out options in open innovation

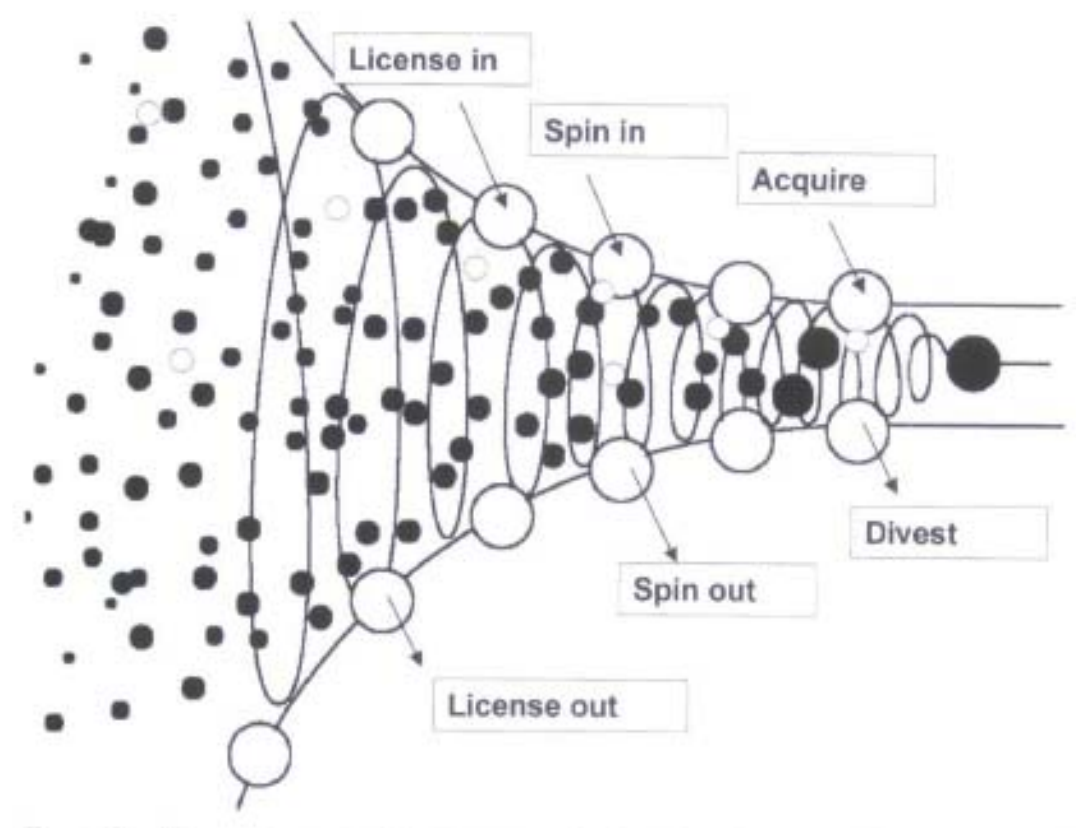

Source: Kirschbaum (2005)

Whether the innovator licences IP, spins out a venture, or develops a new product has a profound impact on the return of the cooperation for the lead user. When the collaboration starts, lead users should be aware of the fact that different exit scenarios are possible. Lead-users will, of course, be interested in collaborating to create a new product and strengthen in that way their competitive position in the product market. However, radical innovations take a long time to reach the market and the chance to have a successful product launch is small. The innovating firm might decide to cancel the project, to licence the related IP, or to spin it out. All these options might seriously affect the lead user. It is, therefore important that they negotiate up front what will happen in these scenarios. Lead users - especially small firms - should also be aware that large companies might be interested to acquire them, because they could be critical in the further development or commercialisation of a radical innovation. Open innovation also opens opportunities for the lead-users. They may be the first candidate to in-licence the technology. They may also participate in the spin-out when the innovating firm decides to take that direction. In short, open innovation may create some serious management challenges for a lead-user but it creates new business opportunities as well.

Finally, lead-users may benefit in an indirect way from the 'inbound' open innovation activities of the innovating firm. The latter can choose to scout new technologies, to have 
extensive research deals with universities and research-labs, to licence-in technology and to spin in external ventures. These different alternatives to tap into externally generated technologies give the innovating firm the option to take fewer risks by internalising radical innovation projects in a later stage (Vanhaverbeke et al., 2008). In this way, innovating companies do not always have to invite lead-users in an early stage which reduces the probability of tensions between them as a result of high technology and market risks.

We should keep in mind that lead-users collaborate with innovating companies to improve the performance of their products or services. Consequently, when an innovator decides not to proceed with the development of the product, lead-users are confronted with serious problems. Even if the innovating company decides to licence the IP or to spin-off the venture, lead-users have to take tough decisions. This is even more pronounced in the case where tacit knowledge is involved. Transfer of IP or the divestment of the venture will may cut of the lead-user from the tacit or contextual knowledge of the original innovating company. Finally, in many of these cases, lead-users have to find a new partner to further develop the innovative product. As a new partnership has to be established, transaction problems may emerge, prior personal networks might not be present, trustful relations may be hard to establish and new potential innovation partners may be competitors of the original innovator. All these implementation problems indicate that open innovation may generate new options for lead-users in theory, but in practice it might be too difficult to realise those benefits.

\section{Conclusions and discussion}

In this study, we reframed the role of lead users in radical innovations by blending insights from open innovation with the existing literature on lead user cooperation in the context of radical innovations. We focused on potential contributions of the open innovation framework for a better understanding of the role of lead users in B2B industries.

First, the 'business model' concept is a centrepiece in open innovation and can improve our understanding of the role of lead users by focusing our attention on value creation and value capturing. The value creation process is the underlying driver through which customer interaction contributes to the technology commercialisation process. Next, the role of lead users should not be analysed within the dyadic relationship with the innovating firms if value is created for target customers downstream the value chain. The process view on the role of lead-user interactions also offers several opportunities to improve the business model concept: the business model is usually presented in a static way, but is in reality the outcome of continuous interaction between the innovating firms and the lead user.

Open innovation is tightly connected to the innovation funnel, indicating that the open innovation process is a dynamic process. Accordingly, we analysed how the role of lead users varies throughout the funnel. As the commercialisation process migrates through the funnel, the information from lead users becomes more specialised. Furthermore, as the commercialisation process progresses, uncertainty is reduced and a higher level of commitment and trust is needed from both partners to continue the collaboration. The competition between the partners to appropriate value becomes 
increasingly manifest as the business model takes shape during the development and the commercialisation process.

Finally, open innovation broadens the number of options to create value from radical innovations. The innovating firm can licence out the IP, it can create a spin off or it can divest the business. Lead users should be aware of these exit scenarios. They have to consider up front whether they are interested in being a licensee for the technology or how the potential benefits for them change when the innovating company decides to spin off the venture and to sell it to a syndication of venture capitalists or other corporate investors.

Reframing the role of lead users using the three themes as we did in this study has several implications for theory and practice. From a theoretical perspective, there is a strong need to integrate several streams of literature to explain the role of lead users in radical innovations. Although we limited the focus on three themes to reframe the role of lead users, it is obvious that we have combined the business model approach, the stage-gated funnel and the recently developed insights from open innovation and the user innovation literature. The integration of these different theoretical perspectives goes beyond the purpose of this publication, but we encourage scholars to combine these perspectives into a more general framework that unifies theoretical constructs from the strategy and innovation literature into a more encompassing view how firms have to innovate with external partners. Scholars may be interested in a rigorous analysis of the underlying theoretical frameworks that might lead to a better understanding of the collaboration between innovating firms and their external sources of innovation; in our opinion, we need to analysed interactions with external innovation partners in terms of business models (strategy), transactions costs/value (TCE, network view), networks, (the relational view of the firms), (dynamic) capabilities or competencies (RBV) and uncertainty (real options theory).

There are also a number of practical lessons to draw from our analysis. First, the successful collaboration between innovating companies and lead users should be framed in terms of joint value creation and value appropriation. Recognising the value creation potential of a radical innovation can take a long time. The recognition of new business opportunities based on technology push innovations may take time and sometimes requires a long-lasting relationship between the innovating firm and its lead-users before a viable business model emerges. Hence, lead-users are in many cases as committed to the new development as the innovator itself. Lead-users should also determine how they can appropriate value from the innovation. Their investments in time and money in the development and commercialisation of the new product should ultimately lead to a profitable business. There are two remarks to make here. First, lead-users should claim some kind of exclusivity. The new product cannot be sold to competitors for several years or in several applications or markets. Second, in many cases the business can only be developed when other partners in the value chain get committed. As a result, value network management is a prerequisite for the successful introduction of radical innovation (Normann, 2001; Normann and Ramirez, 1993). Finally, open innovation also offers new challenges for lead users: they are determined to bring a new product to the market but if the innovating company is divesting the investment or if they sell IP or spin-off the venture it might not be so easy to continue. Managers of lead-user companies should be aware of these possible challenges and should negotiate upfront what will happen when the partner decides to exit the venture. 


\section{Acknowledgements}

The authors would like to thank Marcel Borgers (University of Southern Denmark) and Chris Tucci (EPFL), the organisers of the symposium 'Organizing for user innovation' at the Annual Conference of AOM at Anaheim in August 2008. In addition, the authors wish to thank the Frank Piller (RTWH Aachen University) and two anonymous reviewers whose comments on an earlier version of the paper have helped us improving it significantly.

\section{References}

Aaker, D., Kumar, V. and Day, G. (2000) Marketing Research, 7th ed., Wiley, New York.

Afuah, A. and Tucci, C. (2001) Internet Business Models and Strategies, Irwin/McGraw Hill, New York.

Arora, A. (2002) 'Licensing tacit knowledge: intellectual property rights and the market for know-how', Economic of Innovation and New Technology, Vol. 4, No. 1, pp.41-59.

Arora, A., Fosfuri, A. and Gambardella, A. (2001) Markets for Technology: The Economics of Innovation and Corporate Strategy, MIT Press, Cambridge, MA.

Bamford,J., Gomes-Casseres, B. and Robinson, M. (2003) Mastering Alliance Strategy: A Comprehensive Guide to Design Management and Organization, Jossey-Bass, San Franscisco, CA.

Brandenburger, A. and Nalebuff, B. (1996) Coopetition, Doubleday, New York.

Chesbrough, H. (2003) Open Innovation: the New Imperative for Creating and Profiting from Technology, Harvard Business School Press, Massachusetts.

Chesbrough, H. and Rosenbloom, R. (2002) 'The role of business model in capturing value from innovation: evidence from Xerox Corporation's technology spin-off companies', Industrial and Corporate Change, Vol. 11, No. 3, pp.529-555.

Chesbrough, H., Vanhaverbeke, W. and West, J. (Eds.) (2006) Open Innovation: Researching a New Paradigm, Oxford University Press, Oxford.

Christensen, C. (1997) The Innovator's Dilemma. When New Technologies Cause Great Firms to Fail, Harvard Business School Press, Massachusetts.

Christensen, C. and Bower, J. (1996) 'Customer power, strategic investment, and the failure of leading firms', Strategic Management Journal, Vol. 17, No. 3, pp.197-218.

Christensen, C. and Raynor,M. (2000) The innovator's solution: Creating and sustaining successful growth, Boston,MA: Harvard Business School Press.

Cooper, R. (1990) 'Stage-gate systems: a new tool for managing new products', Business Horizons, Vol. 33, No. 3, pp.44-54.

Cooper, R. and Kleinschmidt, E. (1994) 'Determinants of timeliness in product development', Journal of Product Innovation Management, Vol. 11, No. 5, pp.381-396.

Dahlander, L. and Magnusson, M. (2005) 'Relationships between open source software companies and communities: observations from Nordic firms', Research Policy, Vol. 34, No. 4, pp.481-493.

Danneels, E. (2004) 'Disruptive technology reconsidered: a critique and research agenda', Journal of Product Innovation Management, Vol. 21, No. 4, pp.246-258.

Davidow, W. (1986) Marketing High Technology, The Free Press, New York.

Docherty, M. (2006) 'Primer on “open innovation": principles and practice', Visions, April 2006, pp.13-17, Product Development and Management Association.

Eisenhardt, K.M. (1989) 'Building theories from case study research', Academy of Management Review, Vol. 14, No. 4, pp.532-550. 
Gummesson, E. (2007a) 'Case study research and network theory: birds of a feather', Qualitative Research in Organisations and Management: An international Journal, Vol. 2, No. 3, pp.226-248.

Gummesson, E. (2007b) 'Case study research', in B. Gustavsson (Ed.): The Principles of Knowledge Creation. Research Methods in the Social Sciences, pp.87-110, Edward Elgar, Cheltenham.

Hamel, G. and Prahalad, C.K. (1994) Competing for the Future: Breakthrough Strategies for Seizing Control of your Industry and Creating the Markets of Tomorrow, Harvard Business School Press, Boston, MA.

Henkel, J. (2006) 'Selective revealing in open innovation processes: the case of embedded Linux', Research Policy, Vol. 37, No. 5, pp.953-969.

Kirschbaum, R. (2005) 'Open innovation in practice', Research and Technology Management, Vol. 48, No. 4, pp.24-30.

Leifer, R., McDermott, C., O'Connor, G., Peters, L., Rice, M. and Veryzer, R. (2000) Radical Innovation: How Mature Companies can Outsmart Upstarts, Harvard Business School Press, Massachusetts.

Leonard, D. and Rayport, J. (1997) 'Spark innovation through empathic design', Harvard Business Review, Vol. 75, No. 6, pp.102-113.

Lettl, C. Herstatt, G. and Gemuenden, H. (2006) 'Learning from users for radical innovation', International Journal of Technology Management, Vol. 33, No. 1, pp.25-44.

Lynn, G., Morone, J. and Paulson, A. (1996) 'Marketing and discontinuous innovation: the probe and learn process', California Management Review, Vol. 38, No. 3, pp.8-37.

Magretta, J. (2002) 'Why business models matter', Harvard Business Review, Vol. 80, No. 5, pp.86-92.

McDermott, C. (1999) 'Managing radical product development in large manufacturing firms: a longitudinal study', Journal of Operations Management, Vol. 17, No. 6, pp.631-644.

McDermott, C. and O'Connor, G. (2002) 'Managing radical innovation: an overview of emergent strategy issues', Journal of Product Innovation Management, Vol. 19, No. 6, pp.424-443.

Mohr, J. (2001) Marketing of High-Technology Products and Innovations, Prentice Hall, New Jersey.

Moriarty, R. and Kosnik, T. (1989) 'High-tech marketing: concepts, continuity and change', Sloan Management Review, Vol. 30, No. 4, pp.7-17.

Normann, R. (2001) Reframing Business: When the Map Changes the Landscape, John Wiley, Chichester, UK.

Normann, R. and Ramirez, R. (1993) 'From value chain to value constellation: designing interactive strategy', Harvard Business Review, Vol. 71, No. 4, pp.65-77.

O'Connor, G. (2006) 'Open, radical innovation: toward an integrated model in large established firms', in Chesbrough, H., Vanhaverbeke, W. and West, J. (Eds.): Open innovation: Researching a New Paradigm, pp.62-81, Oxford University Press, Oxford.

O’Connor, G. and Rice, M. (2001a) 'Opportunity recognition and breakthrough innovation in large established firms', California Management Review, Vol. 43, No. 2, pp.95-116.

O'Connor, G. and Veryzer, R. (2001b) 'The nature of market visioning for technology-based radical innovation', Journal of Product Innovation Management, Vol. 18, No. 4, pp.231-246.

O'Connor, G., Leifer, R., Paulson, A. and Peters, L. (2008) Grabbing Lightning: Building a Capability for Breakthrough Innovation, Jossey-Bass, San-Francisco, CA.

Porter, M. (1980) Competitive Strategy, Free Press, New York.

Rice, M., Kelley, D., Peters, L. and O'Connor, G. (2002a) 'Radical innovation: triggering initiation of opportunity recognition and evaluation', $R \& D$ Management, Vol. 31, No. 4, pp.409-420.

Rice, M.P., Leifer, R. and O’Connor, G., (2002b) 'Commercializing discontinuous innovations: bridging the gap from discontinuous innovation project to operations', IEEE Transactions on Engineering Management, Vol. 49, No. 4, pp.330-340. 
Shanklin, W. and Ryans, J. (1987) Essentials of Marketing High Technology, Lexington Books, Massachusetts.

Slater, S. and Nayer, J. (1998) 'Customer-led and market oriented: let's not confuse the two', Strategic Management Journal, Vol. 19, No. 10, pp.1001-1006.

Vanhaverbeke, W. and Cloodt, M. (2006) 'Open innovation in value networks', in Chesbrough, H., Vanhaverbeke, W. and West, J. (Eds.): Open Innovation: Researching a New Paradigm, Oxford University Press, Oxford.

Vanhaverbeke, W., Van de Vrande, V. and Chesbrough, H. (2008) 'Understanding the advantages of open innovation practices in corporate venturing in terms of real options', Creativity and Innovation Management, Vol. 17, No. 4, pp.251-258.

Veryzer Jr., R.W. (2003) 'Discontinuous innovation and the new product development process', Journal of Product Innovation Management, Vol. 15, No. 4, pp.304-321.

von Hippel, E. (1986) 'Lead users: a source of novel product concepts', Management Science, Vol. 32, No. 7, pp.791-805.

von Hippel, E. (2005) Democratizing Innovation, MIT Press, Cambridge:,MA.

von Hippel, E., Thomke, S. and Sonnack, M. (1999) 'Creating breakthroughs at 3M', Harvard Business Review, Vol. 77, No. 5, pp.47-57.

Weick, K. (1979) 'Cognitive processes in organizations', Research in Organizational Behavior, Vol. 1, pp.41-74.

Williamson, O. (1975) Markets and Hierarchies: Analysis and Antitrust Implications, Study in the Economics of Internal Organization, Free Press, New York.

Williamson, O. (1985) The Economic Institutions of Capitalism: Firms, Markets, Relational Contracting, Free Press, New York.

Yin, R. (2003) Case Study Research: Design and Methods, 3rd ed., Sage Publications, Thousand Oaks.

\section{Notes}

1 For more information about the company, see www.dsm.com.

2 http://www.dsm.com/en_US/html/hpf/home_dyneema.htm 